\title{
The isolation of bioactive flavonoids from Jacaranda obtusifolia H. B. K. ssp. rhombifolia (G. F. W. Meijer) Gentry
}

\author{
SORACHAI KHAMSAN ${ }^{1}$ \\ SAISUNEE LIAWRUANGRATH ${ }^{2}$ \\ APHIWAT TEERAWUTKULRAG ${ }^{2}$ \\ STEPHEN G. PYNE 3 \\ MARY J. GARSON ${ }^{4}$ \\ BOONSOM LIAWRUANGRATH ${ }^{1, *}$ \\ ${ }^{1}$ Faculty of Pharmacy, Department of \\ Pharmaceutical Science, Chiang Mai \\ University, Chiang Mai, 50200 Thailand \\ 2 Faculty of Science, Department of \\ Chemistry and Center for Innovation \\ in Chemistry, Chiang Mai University \\ Chiang Mai, 50200 Thailand \\ ${ }^{3}$ School of Chemistry, University of \\ Wollongong, Wollongong, NSW \\ 2522 Australia \\ 4 School of Chemistry and Molecular \\ Biosciences, The University of Queensland, \\ Brisbane, QLD, 4072 Australia
}

\begin{abstract}
The paper describes the bioassay-guided isolation, structure elucidation and anticancer evaluation of five flavonoids (-)-liquiritigenin (1), (-)-neoliquiritin (2), isoliquiritigenin (3), isoliquiritin (4) and formononetin (5) from the twigs of Jacaranda obtusifolia H. B. K. ssp. rhombifolia (G. F. W. Meijer) Gentry. The structures were elucidated based on ${ }^{1} \mathrm{H},{ }^{13} \mathrm{C}$ NMR, comprehensive 2D NMR, MS analyses and comparison with previously reported spectral data. Compounds $\mathbf{1}$ and $\mathbf{3}$ were demonstrated to be inhibitory in vitro against NCI-H187 (small cell lung cancer) with $I C_{50}$ values of 30.1 and $16.6 \mu \mathrm{g} \mathrm{mL}^{-1}$, respectively. The isolates were non-cytotoxic to Vero cells (African green monkey kidney).
\end{abstract}

Keywords: Jacaranda obtusifolia (Bignoniaceae), flavonoids, anticancer activity

Accepted April 5, 2012

Jacaranda is one of the genera of Bignoniaceae endemic to South America and is now widely distributed in the tropical and subtropical areas of the world. Some species are used in traditional medicine in various countries for the treatment of wounds, rheumatism, colds and skin diseases (1). More recently, a review of the ethnobotanical and pharmacological uses of Jacaranda species has pointed out its interesting phytochemical constituents and biological activities such as anti-dyspeptic, cytotoxic, anti-malarial and lipooxygenase inhibitory activity as well as antimicrobial activities (2). Jacaranda obtu-

\footnotetext{
*Correspondence; e-mail: liawruangrath@gmail.com
} 
sifolia H. B. K. ssp. rhombifolia (G. F. W. Meijer) Gentry is a medium-sized, deciduous tree with a variably shaped crown and is now commonly cultivated in Thailand (3). Previously, we reported the isolation and structure elucidation of a 7-hydroxy-3'-methoxy-4'-O- $\beta$-D-glucoside isoflavone, daidzein, and genistin from J. obtusifolia. The isolated compounds possess significant anticancer activity (4). Therefore, in continuation of this work we focused on the isolation of different fractions and subfractions of J. obtusifolia and evaluation of their anticancer activity.

\section{EXPERIMENTAL}

\section{General experimental procedures}

All NMR spectra were recorded on a Bruker Avance (500 MHz) spectrometer (USA). ${ }^{1} \mathrm{H}$ and ${ }^{13} \mathrm{C}$ spectra were recorded relative to $\mathrm{MeOH}-d_{4}(\delta=3.30$ and $49.0 \mathrm{ppm}$, respectively). Low resolution electrospray ionization mass spectra (LR-ESIMS) were measured on a Finnigan MAT 900 XL double focusing magnetic sector mass spectrometer (Finnigan, Germany). Optical rotations were measured on a Perkin-Elmer 241 MC polarimeter (USA) with a 10-cm path length. Reverse phase TLC was carried out on precoated silica gel aluminium-backed plates (RP-18 $\mathrm{F}_{254 \mathrm{~s}}, 0.25 \mathrm{~mm}$ thick, Merck, Germany). The plates were first viewed under UV light at 254 and $365 \mathrm{~nm}$, then spotted using $3 \%$ cerium sulfate in $2 \mathrm{~mol} \mathrm{~L}^{-1} \mathrm{H}_{2} \mathrm{SO}_{4}$, followed by heating. Flash column chromatography was carried out using $\mathrm{RP}_{-} \mathrm{C}_{18}$ silica gel $(40-60 \mu \mathrm{m}$, Merck). Reverse phase high performance liquid chromatography (RP-HPLC) was performed on an Agilent 1100 system (USA) with UV detection at $254 \mathrm{~nm}$ using a Phenomenex Gemini $(5 \mu \mathrm{m}) \mathrm{C}_{18}(10 \mathrm{~mm} \times 250 \mathrm{~mm})$ semipreparative column.

\section{Plant material}

Twigs of J. obtusifolia were collected in July 2008. The plant material was identified by J. F. Maxwell (Department of Biology, Faculty of Science, Chiang Mai University, Thailand), and a voucher specimen was deposited at the CMU Herbarium and Faculty of Pharmacy, of the same university.

\section{Extraction and isolation}

Dried twigs of J. obtusifolia $(1 \mathrm{~kg})$ were ground and extracted successively with $2.5 \mathrm{~L}$ of $n$-hexane, $\mathrm{CHCl}_{3}$ and $\mathrm{MeOH}$ at room temperature, followed by filtration through a Whatman No. 1 filter paper. The hexane, $\mathrm{CHCl}_{3}$ and $\mathrm{MeOH}$ extracts were concentrated under vacuum using a rotary evaporator (Büchi, Switzerland) to afford crude extracts as follows: crude hexane extract (dark green syrup $2.8 \mathrm{~g}$ ), crude $\mathrm{CHCl}_{3}$ extract (brownish sticky solid $7.6 \mathrm{~g}$ ) and crude $\mathrm{MeOH}$ extract (dark brownish sticky solid $9.3 \mathrm{~g}$ ), and were then stored in the refrigerator.

The methanolic extract $(0.88 \mathrm{~g})$ was purified by reverse-phase flash column chromatography on $\mathrm{RP}^{-\mathrm{C}_{18}}$ silica gel (160 g) with gradient elution using $\mathrm{MeOH} / \mathrm{H}_{2} \mathrm{O} ; 25: 75$, $50: 50,75: 25$ and $100: 0, V / V$, each $300 \mathrm{~mL}$ (each collection was $100 \mathrm{~mL}$ ) in the order of 
decreasing polarity. The eluents were collected, monitored by TLC and ${ }^{1} \mathrm{H}$ NMR, producing 7 groups of eluting fractions. The solvents were evaporated to dryness in vacuo to afford 7 major fractions: J1 (0.15 g), J2 (0.03 g), J3 (0.34 g), J4 (0.02 g), J5 (0.05 g), J6 $(0.02 \mathrm{~g})$ and J7 (0.02 g). Fraction J3 was further purified by RP-HPLC. Elution was conducted initially with $50 \% \mathrm{MeOH} / \mathrm{H}_{2} \mathrm{O}$ up to $100 \% \mathrm{MeOH}$ (for $40 \mathrm{~min}$, flow rate $1.5 \mathrm{~mL}$ $\mathrm{min}^{-1}$, UV detection at $254 \mathrm{~nm}$ ) to give 9 subfractions: J31 to J39 (compound 1, $2.2 \mathrm{mg}, t_{\mathrm{R}}$ $=20.2 \mathrm{~min})$. Subfraction J32 (5 mg) was purified by RP-HPLC using the same conditions to give 4 subfractions J321-J324. J323 (2.2 mg) was subjected to further RP-HPLC purification $\left(60 \% \mathrm{MeOH} / \mathrm{H}_{2} \mathrm{O}\right.$ up to $\left.100 \% \mathrm{MeOH}\right)$ to afford compounds $2\left(1.2 \mathrm{mg}, t_{\mathrm{R}}=12.7\right.$ $\mathrm{min})$ and $4\left(0.75 \mathrm{mg}, t_{\mathrm{R}}=19.0 \mathrm{~min}\right)$. Fraction $\mathbf{J} 5(30 \mathrm{mg})$ was purified by RP-HPLC using gradient elution from $\mathrm{MeOH} /$ water $(80: 20)$ to $100 \% \mathrm{MeOH}$ to afford compounds 3 (1.5 $\left.\mathrm{mg}, t_{\mathrm{R}}=11.6 \mathrm{~min}\right)$ and $5\left(0.8 \mathrm{mg}, t_{\mathrm{R}}=12.8 \mathrm{~min}\right)($ Scheme 1$)$.

\section{Anticancer activity}

Cytotoxic assays of crude extracts and the isolated compounds against three cancerous human-cell lines: KB cell line (epidermoid carcinoma of oral cavity, ATCC CCL-17), MCF-7 cell line (breast adenocarcinoma, ATCC HTB-22) and NCI-H 187 cell line (small cell lung carcinoma, ATCC CRL-5804) were performed employing the resazurin microplate assay (REMA) as described by Brien et al. (5) with suitable modification. Briefly, cells in a logarithmic growth phase were harvested and diluted to $7 \times 10^{4}$ cells $\mathrm{mL}^{-1}$ for KB and $9 \times 10^{4}$ cells mL $\mathrm{mL}^{-1}$ for MCF-7 and NCI-H 187, in fresh medium. Successively, $5 \mu \mathrm{L}$ of the essential oil was diluted in $5 \% \mathrm{DMSO}$, and $45 \mu \mathrm{L}$ of cell suspension was added to 384-well plates, incubated at $37{ }^{\circ} \mathrm{C}$ in a $5 \% \mathrm{CO}_{2}$ incubator. After the incubation period ( 3 days for KB and MCF-7, and 5 days for NCI-H187), $12.5 \mu \mathrm{L}$ of $62.5 \mu \mathrm{g} \mathrm{mL} \mathrm{m}^{-1}$ resazurin so-

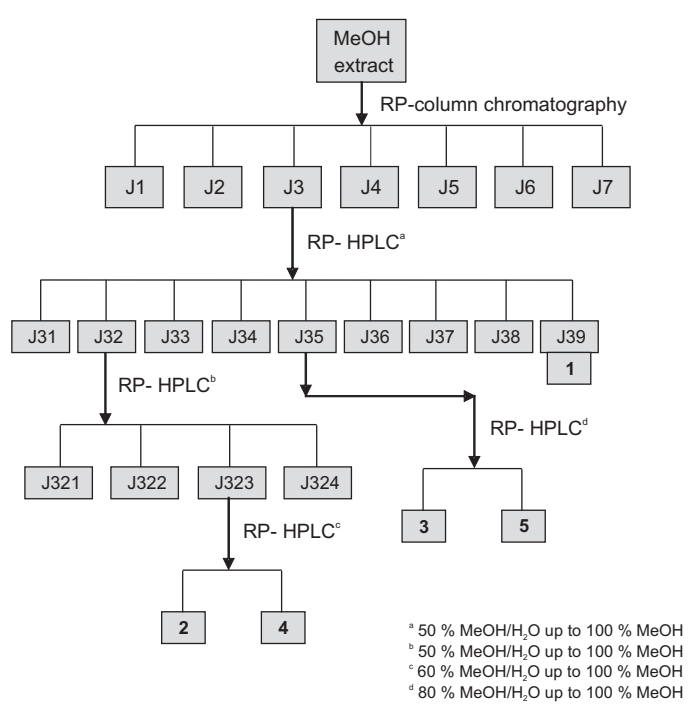

Scheme 1. Isolation scheme for flavonoids from J. obtusifolia. 
lution was added to each well, and the plates were then incubated at $37^{\circ} \mathrm{C}$ for 4 hours. The fluorescence signal was measured using a SpectraMax M5 multi-detection microplate reader (Molecular Devices, USA) at excitation and emission wavelengths of $530 \mathrm{~nm}$ and $590 \mathrm{~nm}$. The inhibitory concentration $\left(I C_{50}\right)$ represented the concentration that caused $50 \%$ reduction in cancer cell line growth. The cytotoxicity assay against Vero cells (African green monkey kidney) was performed using a green fluorescent protein (GFP)-based assay (6).

\section{RESULTS AND DISCUSSION}

The methanolic extract of J. obtusifolia twigs was purified by reverse phase flash column chromatography on $\mathrm{RP}-\mathrm{C}_{18}$ silica gel, followed by reverse phase HPLC purification resulting in the isolation of five flavonoids. The isolated compounds were identified as: (-)-liquiritigenin (1), (-)-neoliquiritin (2), isoliquiritigenin (3), isoliquiritin (4) and formononetin (5). The isolated compounds were identified by spectroscopic analysis $\left({ }^{1} \mathrm{H},{ }^{13} \mathrm{C}\right.$ NMR, 2D NMR and MS) (Fig. 1, Tables I and II). This data was also confirmed by comparison with previously reported spectral data. This extract was selected for its anticancer activity (small cell lung cancer with $I_{50}$ value of $23.2 \mu \mathrm{g} \mathrm{mL}^{-1}$ ) (Table III).

\section{Chemistry}

Compound 1 was isolated as an amorphous yellowish solid. The LR-ESIMS mass spectrum showed the molecular ion peak at $m / z 279.1\left[\mathrm{M}+\mathrm{Na}^{+}\right]$. The ${ }^{1} \mathrm{H}$ NMR (Table I) showed signals for a dihydroflavone: ABX-type aromatic unit at $\delta(\mathrm{ppm})$ of $7.68(1 \mathrm{H}, \mathrm{d}, J$ $=8.8 \mathrm{~Hz}, \mathrm{H}-5), 6.43(1 \mathrm{H}, \mathrm{dd}, J=2.3,8.8 \mathrm{~Hz}, \mathrm{H}-6)$ and $6.27(1 \mathrm{H}, \mathrm{d}, J=2.3 \mathrm{~Hz}, \mathrm{H}-8)$ due to the A ring; AA'BB'-type aromatic unit at $\delta 7.31\left(2 \mathrm{H}, \mathrm{d}, J=8.6 \mathrm{~Hz}, \mathrm{H}-2^{\prime}, 6^{\prime}\right)$ and $6.81(2 \mathrm{H}$, $\left.\mathrm{d}, J=8.6 \mathrm{~Hz}, \mathrm{H}-3^{\prime}, 5^{\prime}\right)$ due to the $\mathrm{B}$ ring. The aliphatic proton signals at $\delta(\mathrm{ppm})$ of 5.35 $(1 \mathrm{H}, \mathrm{dd}, J=3.0,13.0 \mathrm{~Hz}, \mathrm{H}-2), 3.01(1 \mathrm{H}, \mathrm{dd}, J=13.0,16.9 \mathrm{~Hz}, \mathrm{H}-3) 2.66(1 \mathrm{H}, \mathrm{dd}, J=3.0$,
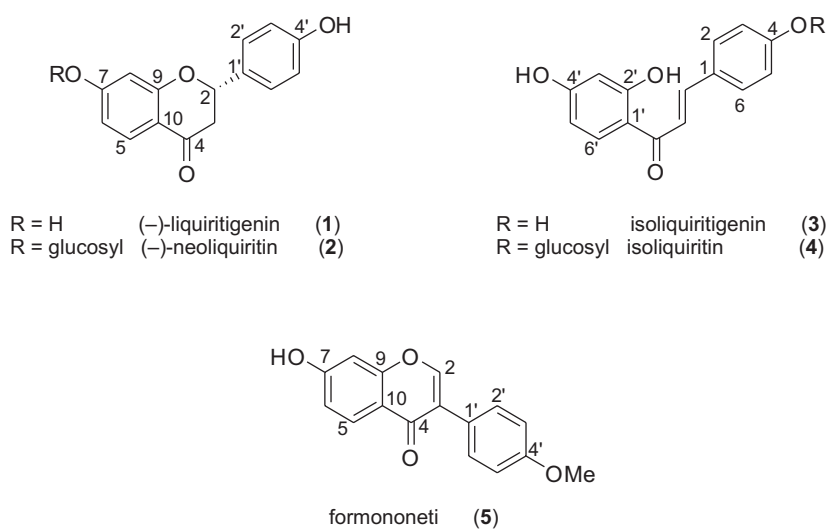

Fig. 1. Structures of flavonoids isolated from the twigs of J. obtusifolia. 
S. Khamsan et al.: The isolation of bioactive flavonoids from Jacaranda obtusifolia H. B. K. ssp. rhombifolia (G. F. W. Meijer) Gentry, Acta Pharm. 62 (2012) 181-190.

$16.9 \mathrm{~Hz}, \mathrm{H}-3)$ were attributed to a $\mathrm{CH}-\mathrm{CH}_{2}$ system. On this basis and comparison of ${ }^{1} \mathrm{H}$ (Table I) and ${ }^{13} \mathrm{C}$ NMR data (Table II) with published values (7) suggested that compound 1 was liquiritigenin. The specific rotation of compound $1\left([\alpha]_{\mathrm{D}}^{21}-11\left(\gamma 0.09 \mathrm{~g} \mathrm{~mL}^{-1}\right.\right.$, $\mathrm{MeOH})$ was comparable to the reported value, $\left([\alpha]_{\mathrm{D}}-10\left(\gamma 1.00 \mathrm{~g} \mathrm{~mL}^{-1}\right.\right.$, EtOH) of $(-)-\mathrm{li}-$

Table I. ${ }^{1} \mathrm{H}$ NMR data of flavonoids from J. obtusifolia

\begin{tabular}{|c|c|c|c|c|c|}
\hline \multirow{2}{*}{ Position } & \multicolumn{5}{|c|}{ Chemical shift $(\delta, \mathrm{ppm})^{\mathrm{a}, \mathrm{b}}$} \\
\hline & 1 & 2 & 3 & 4 & 5 \\
\hline 2 & $\begin{array}{l}5.35 \\
(\mathrm{dd}, 3.0,13.0)\end{array}$ & $\begin{array}{l}5.42 \\
(\mathrm{dd}, 2.5,12.9)\end{array}$ & $7.59(\mathrm{~d}, 8.6)$ & $7.61(\mathrm{~d}, 8.6)$ & $8.02(\mathrm{~s})$ \\
\hline \multirow[t]{2}{*}{3} & $\begin{array}{l}3.01 \\
(\mathrm{dd}, 13.0,16.9)\end{array}$ & $\begin{array}{l}3.10 \\
(\mathrm{dd}, 12.9,16.9)\end{array}$ & $6.83(\mathrm{~d}, 8.6)$ & $6.80(\mathrm{~d}, 8.6)$ & \\
\hline & $\begin{array}{l}2.66 \\
(\mathrm{dd}, 3.0,16.9)\end{array}$ & $\begin{array}{l}2.73 \\
(\mathrm{dd}, 2.7,16.9)\end{array}$ & & & \\
\hline \multicolumn{6}{|l|}{4} \\
\hline 5 & $7.68(\mathrm{~d}, 8.8)$ & $7.80(\mathrm{~d}, 8.8)$ & $6.83(\mathrm{~d}, 8.6)$ & $6.80(\mathrm{~d}, 8.6)$ & $7.91(\mathrm{~d}, 8.9)$ \\
\hline 6 & $\begin{array}{l}6.43 \\
(\mathrm{dd}, 2.3,8.8)\end{array}$ & $\begin{array}{l}6.77 \\
(\mathrm{dd}, 2.2,8.8)\end{array}$ & $7.59(\mathrm{~d}, 8.6)$ & $7.61(\mathrm{~d}, 8.6)$ & $\begin{array}{l}6.75 \\
(\mathrm{dd}, 2.2,8.9)\end{array}$ \\
\hline \multicolumn{6}{|l|}{7} \\
\hline 8 & $6.27(\mathrm{~d}, 2.3)$ & $6.70(\mathrm{~d}, 2.2)$ & $7.58(\mathrm{~d}, 15.4)$ & $7.60(\mathrm{~d}, 15.4)$ & $6.58(\mathrm{~d}, 2.2)$ \\
\hline 9 & & & $7.74(\mathrm{~d}, 15.4)$ & $7.83(\mathrm{~d}, 15.4)$ & \\
\hline \multicolumn{6}{|l|}{10} \\
\hline \multicolumn{6}{|l|}{$1^{\prime}$} \\
\hline $2^{\prime}$ & $7.31(\mathrm{~d}, 8.6)$ & $7.32(\mathrm{~d}, 8.6)$ & & & $7.44(\mathrm{~d}, 8.7)$ \\
\hline $3^{\prime}$ & $6.81(\mathrm{~d}, 8.6)$ & $6.80(\mathrm{~d}, 8.6)$ & $6.20(\mathrm{~d}, 2.4)$ & $6.61(\mathrm{~d}, 2.5)$ & $6.96(\mathrm{~d}, 8.7)$ \\
\hline \multicolumn{6}{|l|}{$4^{\prime}$} \\
\hline $5^{\prime}$ & $6.81(\mathrm{~d}, 8.6)$ & $6.80(\mathrm{~d}, 8.6)$ & $\begin{array}{l}6.35 \\
(\mathrm{dd}, 2.4,9.0)\end{array}$ & $\begin{array}{l}6.69 \\
(\mathrm{dd}, 2.5,8.9)\end{array}$ & $6.96(d, 8.7)$ \\
\hline $6^{\prime}$ & $7.31(\mathrm{~d}, 8.6)$ & $7.32(\mathrm{~d}, 8.6)$ & $7.90(\mathrm{~d}, 9.0)$ & $8.06(d, 8.9)$ & $7.44(\mathrm{~d}, 8.7)$ \\
\hline $1^{\prime \prime}$ & & $5.00(\mathrm{~d}, 7.5)$ & & $5.02(\mathrm{~d}, 7.5)$ & \\
\hline $2^{\prime \prime}$ & & $3.47(\mathrm{~m})$ & & $3.49(\mathrm{~m})$ & \\
\hline 3" & & $3.45-3.48(\mathrm{~m})$ & & $3.46-3.51(\mathrm{~m})$ & \\
\hline $4^{\prime \prime}$ & & $3.41(\mathrm{~m})$ & & $3.41(\mathrm{~m})$ & \\
\hline $5^{\prime \prime}$ & & $3.45-3.48(\mathrm{~m})$ & & $3.46-3.51(\mathrm{~m})$ & \\
\hline \multicolumn{6}{|l|}{$6^{\prime \prime}$} \\
\hline $6 a$ & & $\begin{array}{l}3.87 \\
(\mathrm{dd}, 2.2,12.2)\end{array}$ & & $\begin{array}{l}3.90 \\
(\mathrm{dd}, 12.0,2.2)\end{array}$ & \\
\hline $6 b$ & & $\begin{array}{l}3.67 \\
(\mathrm{dd}, 5.5,12.2)\end{array}$ & & $\begin{array}{l}3.70 \\
(\mathrm{dd}, 12.0,5.4)\end{array}$ & \\
\hline $\mathrm{OMe}$ & & & & & $3.82(\mathrm{~s})$ \\
\hline
\end{tabular}

a Spectra obtained in $\mathrm{CD}_{3} \mathrm{OD}$.

b Coupling constant in $\mathrm{Hz}$. 
quiritigenin and so compound $\mathbf{1}$ had the same configuration as liquiritigenin previously published in the literature (8). Flavanones with a $2 S$ configuration and having a C-2 equatorial aryl group are known to be laevorotatory (9). The C-2 aryl substituent was in the equatorial orientation, as evident from the large $J_{2,3 a x}(13.0 \mathrm{~Hz})$. Thus, the absolute configuration at C-2 of compound $\mathbf{1}$ was confirmed as $S$.

The ${ }^{1} \mathrm{H}$ NMR (Table I) data for compound 2 suggested a structure similar to that of compound 1, differing only in the sugar moiety. An analysis of the sugar unit was completed using DQF-COSY, 1D-TOCSY, HSQC and HMBC data and led to its identification as $\beta$-glucose. The doublet of doublets at $\delta 3.87 \mathrm{ppm}(\mathrm{dd}, J=2.2,12.2 \mathrm{~Hz})$ and at $3.67 \mathrm{ppm}$ $(\mathrm{dd}, J=5.5,12.2 \mathrm{~Hz}$ ), each integrating for one proton, were characteristic of the H-6" pro-

Table II. ${ }^{13} \mathrm{C}$ NMR data of flavonoids from J. obtusifolia

\begin{tabular}{|c|c|c|c|c|c|}
\hline \multirow{2}{*}{ Position } & \multicolumn{5}{|c|}{ Chemical shift $(\delta, \mathrm{ppm})^{\mathrm{a}}$} \\
\hline & 1 & 2 & 3 & 4 & 5 \\
\hline 1 & & & 127.8 & 125.0 & \\
\hline 2 & 80.8 & 79.8 & 131.7 & 131.1 & 152.6 \\
\hline 3 & 44.9 & 43.3 & 117.0 & 116.4 & 123.7 \\
\hline 4 & 193.3 & 192.5 & 161.8 & 163.5 & 176.6 \\
\hline 5 & 129.8 & 128.1 & 117.0 & 116.4 & 126.0 \\
\hline 6 & 113.1 & 110.9 & 131.7 & 131.1 & 118.6 \\
\hline 7 & 165.7 & 164.1 & 192.7 & 192.4 & 171.0 \\
\hline 8 & 104.2 & 103.7 & 118.5 & 115.5 & 102.5 \\
\hline 9 & 169.9 & 163.6 & 145.0 & 145.5 & 159.5 \\
\hline 10 & 113.7 & 115.8 & & & 113.9 \\
\hline $1^{\prime}$ & 131.1 & 129.8 & 113.6 & 115.0 & 124.7 \\
\hline $2^{\prime}$ & 128.8 & 127.8 & 167.8 & 164.5 & 129.9 \\
\hline $3^{\prime}$ & 116.2 & 114.9 & 104.4 & 103.4 & 113.4 \\
\hline $4^{\prime}$ & 159.0 & 153.7 & 169.7 & 165.3 & 159.7 \\
\hline $5^{\prime}$ & 116.2 & 114.9 & 110.8 & 108.0 & 113.4 \\
\hline $6^{\prime}$ & 128.8 & 127.8 & 133.2 & 131.3 & 129.9 \\
\hline $1^{\prime \prime}$ & & 100.1 & & 99.8 & \\
\hline $2^{\prime \prime}$ & & 73.5 & & 73.3 & \\
\hline 3" & & 76.5 & & 76.1 & \\
\hline $4^{\prime \prime}$ & & 69.8 & & 71.6 & \\
\hline $5^{\prime \prime}$ & & 76.5 & & 78.4 & \\
\hline $6^{\prime \prime}$ & & & & & \\
\hline $6 a$ & & 60.9 & & 61.8 & \\
\hline $6 b$ & & 60.9 & & 61.8 & \\
\hline $\mathrm{OMe}$ & & & & & 54.2 \\
\hline
\end{tabular}

a Spectra obtained in $\mathrm{CD}_{3} \mathrm{OD}$. 
tons of the sugar and these signals correlated by HSQC with the carbon at $\delta 60.9 \mathrm{ppm}$. The linkage position of the sugar was established by a heteronuclear multiple bond correlation (HMBC) experiment (Fig. 2), which showed the correlation of the anomeric proton signal at $\delta 5.00 \mathrm{ppm}$ to $\mathrm{C}-7$ at $\delta 164.1 \mathrm{ppm}$. The specific rotation of $2[\alpha]_{\mathrm{D}}^{21}-14(\gamma$ $\left.0.04 \mathrm{~g} \mathrm{~mL}^{-1}, \mathrm{MeOH}\right)$ was comparable to the reported value, $[\alpha]_{\mathrm{D}}-26.7\left(\gamma 0.5 \mathrm{~g} \mathrm{~mL}^{-1}\right.$, $\mathrm{MeOH})(10)$, despite the different concentrations used. Compound 2 was identified as $(-)$-neoliquiritin and indicated that $\mathrm{C}-2$ had the $S$ configuration. In nature, only D sugars occur in abundance. From the negative specific rotation value found, the sugar unit should be $\beta$-D-glucopyranoside (11). The LR-ESIMS displayed a molecular ion peak at $\mathrm{m} / \mathrm{z} 441.0\left[\mathrm{M}+\mathrm{Na}^{+}\right]$in agreement with the structure of compound 2.

The ${ }^{1} \mathrm{H}$ NMR data (Table I) of compound 3 exhibited signals for an ABX-type aromatic unit at $\delta 7.90 \mathrm{ppm}\left(1 \mathrm{H}, \mathrm{d}, J=9.0 \mathrm{~Hz}, \mathrm{H}-6^{\prime}\right), 6.35 \mathrm{ppm}\left(1 \mathrm{H}, \mathrm{dd}, J=2.4,9.0 \mathrm{~Hz}, \mathrm{H}-5^{\prime}\right)$ and $6.20 \mathrm{ppm}(1 \mathrm{H}, \mathrm{d}, J=2.4 \mathrm{~Hz}, \mathrm{H}-3$ ' $)$ due to the A ring; AA'BB'-type aromatic unit at $\delta$ $7.59 \mathrm{ppm}(2 \mathrm{H}, \mathrm{d}, J=8.6 \mathrm{~Hz}, \mathrm{H}-2,6)$ and $6.83 \mathrm{ppm}(2 \mathrm{H}, \mathrm{d}, J=8.6 \mathrm{~Hz}, \mathrm{H}-3,5)$ due to the $\mathrm{B}$ ring; the olefinic proton signals at $\delta 7.74 \mathrm{ppm}(1 \mathrm{H}, \mathrm{d}, J=15.4 \mathrm{~Hz}, \mathrm{H}-9)$, and $7.58 \mathrm{ppm}$ $(1 \mathrm{H}, \mathrm{d}, J=15.4 \mathrm{~Hz}, \mathrm{H}-8)$ were attributed to positions $\beta$ and $\alpha$ of a chalcone skeleton, and the coupling constant of $15.4 \mathrm{~Hz}$ (in $\mathrm{MeOH}-d_{4}$ ) between $\mathrm{H}-8$ and $\mathrm{H}-9$ revealed that the olefinic system had a trans geometry. Comparison of the ${ }^{1} \mathrm{H}$ (Table I) and ${ }^{13} \mathrm{C}$ NMR data (Table II) with previously published spectral data (7) suggested that compound 3 was

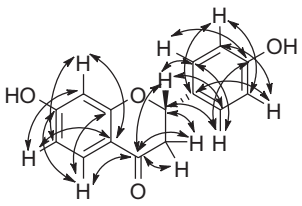

$(-)$-Liquiritigenin

(1)

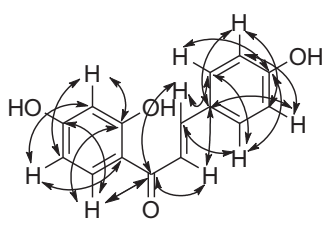

Isoliquiritigenin
(3)

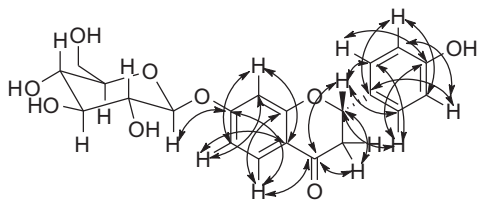

(-)-Neoliquiritin

(2)

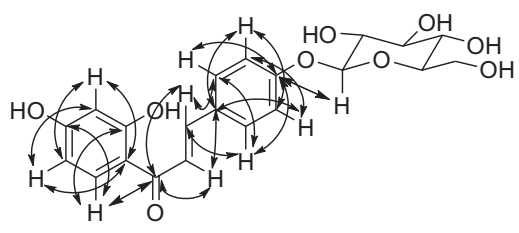

Isoliquiritin

(4)

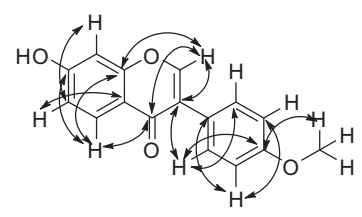

Formononetin

(5)

Fig. 2. Significant HMBC correlations of the isolated flavonoids. 
S. Khamsan et al.: The isolation of bioactive flavonoids from Jacaranda obtusifolia H. B. K. ssp. rhombifolia (G. F. W. Meijer) Gentry, Acta Pharm. 62 (2012) 181-190.

Table III. Anticancer activity of flavonoids isolated from J. obtusifolia

\begin{tabular}{|c|c|c|c|c|}
\hline \multirow{2}{*}{ Sample } & \multirow{2}{*}{ Vero cells } & \multicolumn{2}{|c|}{$I C_{50}{ }^{a}\left(\mu \mathrm{g} \mathrm{mL}^{-1}\right)$} & \multirow{2}{*}{ NCI-H18? } \\
\hline & & KB & MCF-7 & \\
\hline Hexane extract & Non-cytotoxic & Inactive $^{\mathrm{b}}$ & Inactive $^{\mathrm{b}}$ & Inactive $^{b}$ \\
\hline $\mathrm{CHCl}_{3}$ extract & Non-cytotoxic & Inactive $^{\mathrm{b}}$ & Inactive $^{b}$ & Inactive $^{b}$ \\
\hline $\mathrm{MeOH}$ extract & Non-cytotoxic & Inactive $^{\mathrm{b}}$ & Inactive $^{\mathrm{b}}$ & 23.15 \\
\hline (-)-Liquiritigenin (1) & Non-cytotoxic & Inactive $^{\mathrm{b}}$ & Inactive $^{b}$ & 30.11 \\
\hline (-)-Neoliquiritin (2) & Non-cytotoxic & Inactive $^{b}$ & Inactive $^{\mathrm{b}}$ & Inactive $^{b}$ \\
\hline Isoliquiritigenin (3) & Non-cytotoxic & - & - & 16.55 \\
\hline Isoliquiritin (4) & Non-cytotoxic & - & - & Inactive $^{b}$ \\
\hline Formononetin (5) & Non-cytotoxic & - & - & Inactive $^{\mathrm{b}}$ \\
\hline Ellipticine $\mathrm{c}^{\mathrm{c}}$ & 1.67 & 0.51 & & 1.18 \\
\hline Doxorubicine $^{\mathrm{d}}$ & - & 0.34 & 1.18 & 0.058 \\
\hline
\end{tabular}

a Concentration that killed $50 \%$ of cell lines.

${ }^{\mathrm{b}}$ Inactive at $50 \mu \mathrm{g} \mathrm{mL} \mathrm{m}^{-1}$.

c,d Anticancer drugs used as positive controls.

isoliquiritigenin. The LR-ESIMS mass spectrum showed the molecular ion peak at $\mathrm{m} / \mathrm{z}$ $279.1\left[\mathrm{M}+\mathrm{Na}^{+}\right]$, which corresponded to isoliquiritigenin.

Compound 4 showed the molecular ion peak at $m / z 441.0\left[\mathrm{M}+\mathrm{Na}^{+}\right]$in its LR-ESIMS. Compound 4 had a specific rotation of $[\alpha]_{\mathrm{D}}^{21}-53\left(\gamma 0.04 \mathrm{~g} \mathrm{~mL}^{-1}, \mathrm{MeOH}\right)$. The ${ }^{1} \mathrm{H}$ NMR data (Table I) of compound 4 suggested a structure similar to that of compound 3 , differing only in the presence of a $\beta$-glucose moiety. HMBC experiment showed the linkage position of the sugar (Fig. 2), indicating the correlation of an anomeric proton signal at $\delta$ $5.02 \mathrm{ppm}(1 \mathrm{H}, \mathrm{d}, J=7.5 \mathrm{~Hz})$ with $\mathrm{C}-4$ at $\delta 163.5 \mathrm{ppm}$. A comprehensive analysis of DQF-COSY, HSQC and HMBC spectra of compound 4 allowed complete assignment of its proton and carbon signals. On the basis of this finding and from a comparison with literature NMR data (12), compound 4 was identified as isoliquiritin.

Isoflavone 5 showed ${ }^{1} \mathrm{H}$ NMR signals for the ABX-type aromatic unit at $\delta(\mathrm{ppm})$ of $7.91(1 \mathrm{H}, \mathrm{d}, J=8.9 \mathrm{~Hz}, \mathrm{H}-5), 6.75(1 \mathrm{H}, \mathrm{dd}, J=2.2,8.9 \mathrm{~Hz}, \mathrm{H}-6)$ and $6.58(1 \mathrm{H}, \mathrm{d}, J=2.2 \mathrm{~Hz}$, $\mathrm{H}-8)$ due to the A ring; AA'BB'-type aromatic unit at $\delta(\mathrm{ppm})$ of $7.44(2 \mathrm{H}, \mathrm{d}, J=8.7 \mathrm{~Hz}$, $\left.\mathrm{H}-2^{\prime}, 6^{\prime}\right)$ and $6.96\left(2 \mathrm{H}, \mathrm{d}, J=8.7 \mathrm{~Hz}, \mathrm{H}-3^{\prime}, 5^{\prime}\right)$ due to the B ring; the $\delta$ of $8.02 \mathrm{ppm}(1 \mathrm{H}, \mathrm{s})$ signal was attributed to a proton of ring $\mathrm{C}$ and there was also a methoxy substituent at $\delta$ $3.82 \mathrm{ppm}\left(3 \mathrm{H}, \mathrm{s},-\mathrm{OCH}_{3}\right)$ (Table I). The linkage position of $-\mathrm{OCH}_{3}$ was obtained from an HMBC experiment (Fig. 2), which showed the correlation of the proton signal at $\delta 3.82$ $\operatorname{ppm}(3 \mathrm{H}, \mathrm{s})$ with C-4' at $\delta 159.7 \mathrm{ppm}$. Compound 5 exhibited the molecular ion peak at $m / z 291.0\left[\mathrm{M}+\mathrm{Na}^{+}\right]$in its LR-ESIMS. Comparison with the previously reported data (13) indicated that compound 5 was formononetin. 


\section{Anticancer activity}

The methanolic extract exhibited anticancer activity against the NCI-H187 cancer cell line with an $I C_{50}$ value of $23.2 \mu \mathrm{g} \mathrm{mL} \mathrm{m}^{-1}$. The $I C_{50}$ values of isolated compounds are presented in Table III. Isoliquiritigenin (3) exhibited the most potent anticancer activity against NCI-H187 with an $I C_{50}$ of $16.6 \mu \mathrm{g} \mathrm{mL}^{-1}$, while (-)-liquiritigenin (1) showed moderate anticancer activity against NCI-H187 $\left(\mathrm{IC}_{50}=30.1 \mu \mathrm{g} \mathrm{mL}-1\right)$. In addition, isolated compounds 1-5 showed no cytotoxicity against Vero cells (African green monkey kidney). Ellipticine and doxorubicine were used as positive controls. Ellipticine showed anticancer activity against KB and NCI-H 187 cell lines with the $I_{50}$ values of 0.5 and $1.2 \mu \mathrm{gL}^{-1}$, respectively. Doxorubicine exhibited activity toward KB, MCF-7 and NCI-H 187 cell lines with the $I C_{50}$ in the range of $0.06-0.34 \mu \mathrm{g} \mathrm{mL}-1$.

\section{CONCLUSIONS}

Bioactivity-guided fractionation of the active methanolic extract of the J. obtusifolia twigs led to the isolation of (-)-liquiritigenin (1), (-)-neoliquiritin (2), isoliquiritigenin (3), isoliquiritin (4) and formononetin (5). (-)-Liquiritigenin (1) and isoliquiritigenin (3) were demonstrated to be active constituents against NCI-H187 (small cell lung cancer) with $I C_{50}$ values of 30.1 and $16.6 \mu \mathrm{g} \mathrm{mL}^{-1}$, respectively, but were non-cytotoxic to Vero cells (African green monkey kidney).

Therefore, the anticancer activity of the isolated flavonoids supports the documented folklore usage of the extracts of this plant to treat cancers.

Acknowledgments. - The authors gratefully acknowledge the Commission on Higher Education for financial support. We thank the Graduate School, Faculty of Pharmacy, Chiang Mai University, and the School of Chemistry and Molecular Biosciences, The University of Queensland for laboratory facilities. In addition, we also thank PERCH-(CIC), CMU.

\section{REFERENCES}

1. R. M. Ali and P. J. Houghton, A new phenolic fatty acid ester with lipoxygenase inhibitory activity from Jacaranda filicifolia, Planta Med. 65 (1999) 455-457; DOI: 10.1055/s-2006-960811.

2. M. S. Gachet and W. Schühly, Jacaranda - An ethnopharmacological and phytochemical review, J. Ethnopharmacol. 121 (2009) 14-27; DOI: 10.1016/j.jep.2008. 10.015.

3. T. Smitinan and K. Larsen, Flora of Thailand, The Chutima Press, Bangkok 1987.

4. S. Khamsan, S. Liawruangrath, A. Teerawutkulrag, S. G. Pyne, M. J. Garson and B. Liawruangrath, A new isoflavone from Jacaranda obtusifolia H.B.K. ssp. rhombifolia (G.F.W. Meijer) Gentry, Acta Pharm. Sci. 53 (2011) 181-188.

5. J. O. Brien, I. Wilson, T. Orton and F. Pognan, Investigation of the alamar blue (resazurin) fluorescent dye for the assessment of mammalian cell cytotoxicity, Eur. J. Biochem. 267 (2000) 5421-5426; DOI: $10.1046 / j .1432-1327.2000 .01606 . x$.

6. L. Hunt, M. Jordan, M. De Jesus and F. M. Wurm, GFP expressing mammalian cells for fast, sensitive, noninvasive cell growth assessment in a kinetic mode, Biotechnol. Bioeng. 65 (1999) 201-205; DOI: 10.1002/(SICI)1097-0290(19991020)65:2< 201::AID-BIT10>3.0.CO;2-H. 
7. C.-J. Ma, G.-S. Li, D.-L. Zhang, K. Liu and X. Fan, One step isolation and purification of liquiritigenin and isoliquiritigenin from Glycyrrhiza uralensis Risch. using high-speed counter-current chromatography, J. Chromatogr. A 1078 (2005) 188-192; DOI: 10.1016/j.chroma.2005.01.053.

8. N. I. Kulesh, N. A. Vasilevskaya, M. V. Veselova, V. A. Denisenko and S. A. Fedoreev, Minor polyphenols from Maackia amurensis wood, Chem. Nat. Compds. 44 (2008) 712-714; DOI: 10.1007/ s10600-009-9195-3.

9. E. Garo, J.-L. Wolfender, K. Hostettmann, W. Hiller, S. Antus and S. Mavi, Prenylated flavanones from Monotes engleri. online structure elucidation by LC/UV/NMR, Helv. Chim. Acta 81 (1998) 754-763; DOI: 10.1002/hlca.19980810325.

10. J. Li, S. Kadota, Y. Kawata, M. Hattori, G. Xu and T. Namba, Constituents of the roots of Cynanchum bungei Decne. Isolation and structures of four new glucosides, bungeiside A, B, C, and D, Chem. Pharm. Bull. 40 (1992) 3133-3137.

11. W. Fan, Y. Tezuka, K. M. Ni and S. Kadota, Prolyl endopeptidase inhibitors from the underground part of Rhodiola sachalinensis, Chem. Pharm. Bull. 49 (2001) 396-401.

12. B. Fu, H. Li, X. Wang, F. S. C Lee and S. Cui, Isolation and identification of flavonoids in licorice and a study of their inhibitory effects on tyrosinase, J. Ag. Food Chem. 53 (2005) 7408-7414; DOI: 10.1021/jf051258h.

13. T. Han, H. Li, Q. Zhang, H. Zheng and L. Qin, New thiazinediones and other components from Xanthium strumarium, Chem. Nat. Compds. 42 (2006) 567-570; DOI: 10.1007/s10600-006-0215-2.

\section{$S A \check{Z} E T A K$}

\section{Izolacija bioaktivnih flavonoida iz biljke Jacaranda obtusifolia H. B. K. ssp. rhombifolia (G. F. W. Meijer) Gentry}

SORACHAI KHAMSAN, SAISUNEE LIAWRUANGRATH, APHIWAT TEERAWUTKULRAG, STEPHEN G. PYNE, MARY J. GARSON i BOONSOM LIAWRUANGRATH

U radu je opisana izolacija, određivanje strukture i antitumorsko djelovanje pet flavonoida: ( )-likviritigenina (1), ( )-neolikviritina (2), izolikviritigenina (3), izolikviritina (4) i formononetina (5) iz plodova biljke Jacaranda obtusifolia H. B. K. ssp. rhombifolia (G. F. W. Meijer) Gentry. Strukture su određene na temelju ${ }^{1} \mathrm{H},{ }^{13} \mathrm{C}$ NMR, 2D NMR, MS i usporedbom s ranije objavljenim spektroskopskim podacima. Spojevi 1 i 3 imaju inhibitorni učinak in vitro na tumorsku staničnu liniju raka pluća NCI-H187 (IC 50 vrijednost 30,1, odnosno 16,6 $\mu \mathrm{g} \mathrm{mL}{ }^{1}$ ). Izolirani flavonoidi nisu citotoksični za Vero stanice (bubrežne stanice afričkog zelenog majmuna).

Ključne riječi: Jacaranda obtusifolia (Bignoniaceae), flavonoidi, antitumorsko djelovanje

Faculty of Pharmacy, Department of Pharmaceutical Science, Chiang Mai University, Chiang Mai, 50200 Thailand

Faculty of Science, Department of Chemistry and Center for Innovation in Chemistry, Chiang Mai University, Chiang Mai, 50200 Thailand

School of Chemistry, University of Wollongong, Wollongong, NSW, 2522 Australia

School of Chemistry and Molecular Biosciences, The University of Queensland, Brisbane, QLD, 4072 Australia 